EDITORIAL

\title{
Five Propositions for Genuine Students as Partners Practice
}

Kelly E. Matthews University of Queensland, Brisbane, Queensland, Australia Contact: k.matthews1@uq.edu.au

Students as partners ( $\mathrm{SaP}$ ) is a metaphor for university education that challenges traditional assumptions about the identities of, and relationships between, learners and teachers. Through the surprising (to some) juxtaposition of "student" and "partner," this metaphor imagines and makes way for respectful, mutually beneficial learning partnerships where students and staff work together on all aspects of educational endeavours. SaP offers hope for students and staff seeking relational approaches to learning - built on and through dialogue - that enable shared responsibility and joint ownership for teaching, learning, and assessment. Because of its focus on dialogic practices, partnership provides a counter-narrative to current neoliberal agendas that translate into client-commoditycustomer discourses of students and fee-for-service models of higher education driven by economic forces that trump broader social agendas.

If we think of student-staff partnerships as "a collaborative, reciprocal process through which all participants have the opportunity to contribute equally, although not necessarily in the same ways, to curricular or pedagogical conceptualization, decisionmaking, implementation, investigation, or analysis" (Cook-Sather, Bovill, \& Felten, 2014, pp. 6-7), then partnerships can unfold in teaching, learning, and assessment activities or through subject-based research and inquiry approaches, including the scholarship of teaching and learning (SoTL), or in curriculum development efforts where students can become teaching consultants (Bovill, 2013; Healey, Flint, \& Harrington, 2014). As "a joint endeavour to shape and influence university teaching and learning," I have argued that SaP is an ethos "that values the collaborative interaction between all members of the university community" (Matthews, 2016, p. 3). Although the metaphor explicitly names "students" to intentionally and clearly assert the role students can assume alongside others with educational expertise, partnerships can involve: students with students, students with staff, students with senior university administrators, and students with alumni or members of industry.

As $\mathrm{SaP}$ is gaining momentum in many higher education institutions globally (Matthews, Cook-Sather, \& Healey, in press), I believe it is important to draw together various threads of research and practice into overarching principles that can guide partnership approaches. Inspired by Felten, my intention is not to espouse the principles of good practice in SaP, but rather to offer these propositions as a springboard for practitioners that both attends to and encourages a diversity of approaches that "can serve

CC-BY Licence 4.0 This is an Open Access article distributed under the terms of the Creative Commons - Attribution License 4.0 International (https://creativecommons.org/licenses/by/4.0/), which permits unrestricted use, distribution, and reproduction in any medium, provided the original work is properly attributed. 
as a heuristic for understanding and evaluating work in our field" (2013, p. 121). With that in mind, this editorial offers five guiding propositions underpinning genuine SaP approaches. Good practice should aspire to:

1. Foster inclusive partnerships

2. Nurture power-sharing relationships through dialogue and reflection

3. Accept partnership as a process with uncertain outcomes

4. Engage in ethical partnerships

5. Enact partnership for transformation

These propositions interweave varying strands of scholarly works (Bryson, Furlonger, \& Rinaldo-Langridge, 2016; Cook-Sather et al., 2014; Healey et al., 2014) and my experiences of partnership with insights from critical theorists. My goal is to illuminate power relationships and offer a tapestry of principles intended to guide practitioners. I hope they spark dialogue amongst those in partnership, while catalysing discussion and debate more broadly as we seek to engage in genuine partnerships and advocate for SaP as a way forward for higher education.

\section{FOSTERING INCLUSIVE PARTNERSHIPS}

"Who engages in SaP?," and "what is the form of the partnership practice?", are two important, interrelated questions that must be considered in terms of fostering inclusive partnerships. There are no 'step-by-step instructions' or a 'cookbook recipe' for partnership, which is enacted based on creativity of the people involved who translate the ethos of SaP into practice. As Bovill stated, "all SaP projects will look different and involve different actors" (2017, p. 3).

Without reflecting on diversity and inclusion, a risk is that SaP may be biased in favour of "like students" partnering with "like staff", which is particularly worrisome in paired or small group partnerships where students or staff are recruited through some selection process. Indeed, Mercer-Mapstone et al. (2017) found that most SaP work reported in their literature review took this form. Bourdieu's $(1988,2003)$ theorising on power in societal structures, including universities, illuminated the role of habitus, or our unconsciously formed habits, dispositions, and preferences that are both influenced by our position in society, while also influencing our preferences and choices in our daily lives. In other words, without thinking about it, we will tend to be drawn to partnerships with people like us. For Bourdieu, this unconscious process reproduces the existing power structures in societies. This presents the risk of socialising students to the existing language and practices of higher education, rather than challenging and reframing them. As Greene lamented, "I have not easily come to terms with the ways in which what education permits and forbids in different people's experiences too often follows the lines of class, gender, and race" (1994, p. 2).

In higher education, SaP needs to create spaces for participation and partnerships where members from differing social classes, countries, backgrounds, religions, disciplines, and so on, can work together on teaching and learning. Cook-Sather and Agu highlighted the transformative power for equity-seeking students who are included in SaP: "In one student's words, the experience of being positioned as a partner 'made me feel like who I am is more than enough - that my identity, my thoughts, my ideas are significant and valuable'" (2013, p. 277). Drawing on Bourdieu, partnerships engaging participants with differing habitus, 
who engage in reflectivity, are beginning the important journey of disrupting traditional hierarchies in higher education structures.

Fostering inclusive SaP begins with acknowledging the diversity of our student and staff populations, and then reflecting on the design of our SaP programs, to reveal ways in which they may unintentionally be catering to certain students and staff while excluding others. Several important works (for examples see: Bovill, Cook-Sather, Felten, Millard \& Moore-Cherry, 2016; Cook-Sather \& Agu, 2013; Bell et al., 2017) and projects unfolding (for example see: REACT Project, 2017; Green, 2017) explicitly address diversity, inclusion or cross-cultural learning in SaP. Bovill (2017) offered a framework outlining various levels of participation in partnership, while the Bryson and colleagues' (2016) Model A--Model B framework highlights the spectrum of opportunities for SaP from paired or small group partnerships where students are selected and typically working with staff in an extracurricular capacity, to partnership enacted in the assessed curriculum that reaches more students.

Ideally, institutions will direct attention to the experiences of a diversity of students as the focus of partnership work, while also offering a plethora of partnership opportunities that specifically seek to include students and staff from all backgrounds in meaningful, power-sharing learning partnerships that shape the university.

\section{NURTURING POWER-SHARING RELATIONSHIPS THROUGH DIALOGUE AND REFLECTION}

Power, whether discussed or left unspoken, is always a factor in SaP interactions. The intention of SaP is not to eliminate power or tip the scales of power in favor of one group over the other. As Foucault (1982) suggested, power is ubiquitous, so trying to get rid of it is a futile exercise. Bourdieu $(1988 ; 2003)$ grounded power in society and challenged us to be reflective in regard to how power unfolds in social systems where individuals possess certain habits and capital (resources in a broad sense) that either advantage or disadvantage them in social interactions. Theories of power offer a framework to illuminate power in SaP, to discuss it within partnerships, or reflect upon power dynamics as SaP practitioners and researchers.

SaP practitioners should aspire to share power within their partnerships. CookSather and colleagues (2014) framed SaP in terms of equitable contributions by recognising the differing expertise that partners bring based on their experiences, positions, and perspectives. Searle, Gibbons, Haynes, and Potter (2015) linked expertise in partnerships with power generally. Expertise represents an important form of symbolic capital in universities and its possession is associated with power and influence from a Bourdieuian perspective. SaP creates space to re-imagine expertise, particularly that of students in regards to learning, teaching and the student experience in current higher education. By framing expertise in terms of power, partners can explicitly discuss their capital and its unique contribution specific to their position in the university. Through ongoing dialogue about expertise and contributions, and continuous reflection, power is not diminished, but instead shared as all partners come to appreciate the resources (capital) they have to offer. As one example, a partnership of undergraduate students and faculty to redesign a course found that, "By working together to take full advantage of all of the team's expertise, we began to understand the true meaning and importance of shared power through collaboration" (Mihans, Long, \& Felten, 2008, p. 5).

Always attentive to the power dynamics at play, those in partnership benefit from engaging in reflection. As several scholars have argued (e.g. Dewey, 1938; Freire, 1970; 
Schon, 1987), learning happens when we reflect on practice. Thus, simply doing SaP without learning the language, values, or intentions of SaP disadvantages those involved and diminishes the transformative potential of SaP for individuals, the universities, and the broader movement. I do not mean that practitioners must agree on language, follow the same 'recipe', or insist that SaP is a set of specific values. I have argued elsewhere that institutions should grapple with what SaP means in their context and decide together how to talk about partnership as an important part of the cultural change process (Matthews, 2016). Here, I am primarily drawing on Freire's (1970) notion of praxis as both action and reflection unfolding continuously and simultaneously. SaP should create space for open dialogue about the principles of partnership drawing on its language and participants' intentions. For Freire, action without reflection, or conversely reflection without action, is insufficient to transform the realities of those engaged in revolutionary praxis. For SaP, the risk is that those engaged are doing partnership work, even great SaP work, but without any space to reflect on what they are doing and why it matters for themselves and higher education more broadly, it lacks its transformative power for individuals and their institutions.

Several scholars have argued for the centrality of ongoing reflection in SaP (see Kehler, Verwood, \& Smith, 2017; Seale et al., 2014). An important example of reflections on partnership that emphasise the messy, 'work in progress' nature of SaP is Teaching and Learning Together in Higher Education, which inspired the inclusion of reflective essays in this journal.

\section{ACCEPTING PARTNERSHIP AS A PROCESS WITH UNCERTAIN OUTCOMES}

Healey et al. summed up this proposition well by highlighting that SaP "is a way of doing things, rather than an outcome in itself" $(2014$, p. 7). While the process of engaging in partnership is associated with a range of beneficial and desired outcomes for both students and staff (Mercer-Mapstone et al., 2017), the driving force for engaging in SaP is not achievement of any particular, predetermined outcome. This is because, as I have argued, outcomes of "students and staff genuinely working together with a shared sense of responsibility for learning and teaching in higher education will be uncertain and unpredictable" (Matthews, 2017, p. 1). The reciprocal ethos of SaP, where all involved work together through power-sharing and dialogue, gives primacy to the co-creation of shared goals and outcomes that are mutually decided during the process of partnership. As such, the outcomes of SaP are unknown at the beginning of the joint endeavour. Furthermore, the process of partnership extends into the realm of emotions inherent in human relationships, which are central to SaP yet often not discussed in the context of learning in higher education (Felten, 2017).

The significance of partnership is in the process, because through ongoing dialogue participants build the human relationships essential to engagement in learning and teaching, and traditional power hierarchies can be shifted and shared (see Freire, 1970, for more on role of dialogue related to power). This orientation is particularly relevant for partnerships in neoliberal contexts where student satisfaction survey results, employment outcomes, and global rankings dominate the minds of some institutional leaders (Freeman, 2016), who are increasingly divorced from the daily life of academic practice although tasked with strategic planning for teaching, learning, and the student experience (Shepherd, 2014). In such contexts, academics and senior administrators are caught in a web of measureable outcomes to be achieved, which diminishes the time, energy and resources 
devoted to the process of building meaningful, power-sharing learning relationships (see Felten et al., 2016 for insight into place of relationships in successful universities).

A risk for SaP is that it becomes appropriated for neoliberal purposes that shift the discourse of SaP from a relational process to one of achieving outcomes of student satisfaction (which has been observed in terms of student engagement, see Matthews, 2016). In this scenario, the language of SaP is adopted, while the practices become 'watered down' to ensure particular outcomes that maintain the power structures that SaP seek to disrupt.

\section{ENGAGING IN ETHICAL PARTNERSHIPS}

SaP should be governed by ethical guidelines - conducted in an ethical process and for ethical outcomes. While formal ethics approval from committees (institutional research boards) in research or SoTL govern SaP approaches that require them (e.g. informed consent, risk), I am thinking more broadly about ethics as morals or dealing in right and wrong conduct. Healey et al. stated that ethics "provide the tools needed to develop practical compromises between what is correct universally and what is right in particular situations" (2013, p. 25). Ethical behaviour is perhaps assumed in SaP as it is not widely discussed in the literature, although values and principles of mutual benefit are strong, which suggests an ethical foundation. That is, good SaP is good for all involved.

Cook-Sather and Felten (2017) discuss the process of partnership unfolding in "an ethic of reciprocity" that draws on the respect and shared responsibility for learning and teaching (Cook-Sather et al., 2014). As a relational process, "all involved - students, academics, professional services staff, senior managers, students' unions, and so on - are actively engaged in and stand to gain from the process of learning and working together" (Healey et al., 2014, p. 12). Bryson and colleagues argued that SaP is ethical when "all are granted equality of opportunity to participate and all voices, opinions and contributions are listened to and acknowledged with mutual respect and appreciation" (2016, p. 5). I have written that, "Partnership language is being crafted around the joint endeavour of learning predicated on mutually beneficial and rewarding collaborative learning experiences" (Matthews, 2016, p. 3). However, reciprocity does not equate to ethical practice. Thus, explicitly situating SaP as ethical practice becomes important.

Ethical SaP practices involves at least three components. First, the ethics of reciprocal, mutually beneficial practice necessitates a process of power-sharing between all involved. Power-sharing in the sense that power is shared amongst all individuals who bring differing but equally important expertise essential for partnership, and all have opportunity to shape the direction, decisions, and goals of the SaP approach as agreed upon at the onset. Ethical power sharing in partnership is complicated. Building from the student voice movement, care is required to avoid the potential for student participation in SaP to be manipulated or deployed solely for institutional purposes. Second, mutualistic partnerships benefit all involved who are working together for good. However, relationships that benefit all parties can be unethical in nature if the goals or outcomes of the practice are morally questionable. For example, partnerships that collude to mislead, cheat, plagiarize, or 'cut corners' to attain an outcome are unethical. If not caught, then all involved technically benefit and if caught, all share in the risk, and thus while reciprocal, this is hardly ethical.

Finally, ethical practices in learning and teaching partnerships mean serving more than the individuals involved as SaP is part of a broader movement for social good grounded in democratic principles. Or as Dewey (1938) insisted, the experience of education should 
contribute to individual growth in the short term and societal good in the longer term. Barnacle and Dall'Alba recently argued for care in student engagement, which has lessons for SaP and a shared goal of contributing to "an educative process that promotes creativity, critical judgement, and ethical and social understanding towards a more just and caring world" (2017, p. 11). Cook-Sather and Felten (2017) also recently advocated for an ethic of care in $\mathrm{SaP}$, reiterating that partnerships contribute to a greater good than just individualistic advancement.

\section{ENACTING PARTNERSHIP FOR TRANSFORMATION}

"The extent to which we (university communities) value students and staff working collaboratively informs the transformative potential of partnership" (Matthews et al., in press). That is, the potential to create a culture of partnership grounded in the values of respect, reciprocity, and shared responsibility for learning and teaching between students and staff as equal members of the university community. In other words, genuine partnership in learning and teaching is an act of resistance to the traditional, often implicit, but accepted, hierarchical structure where staff have power over students. Drawing again on Bourdieu's theory of power allows us to imagine beyond current approaches to higher education so that SaP can transform learning relationships toward egalitarian learning communities instead of reproducing existing hierarchies that distance learners and teachers in an increasingly neoliberal environment. The tension of transformation, as I imagine it unfolding at the individual, disciplinary, and institutional levels, is the interplay of individual agency versus structural constraints in the field of higher education. Scholars of Bourdieu debate this tension. Like Mills (2008), I interpret Bourdieu's theory of power as making space for the transformative power of individual agency. Practitioners of SaP are first and foremost transforming their own realities by engaging in an alternative form of education within the traditional structures of universities. By connecting with other practitioners and advocating for SaP, they are part of a movement seeking to transform education more broadly.

Being able to think beyond what is and imagine different ways of learning and teaching is perhaps why many of us are engaging in SaP. Cook-Sather and Felten (2017, p. 187) evoked the notion of liminality to position SaP as an 'as if' practice that creates space "to accommodate contingency and responsiveness as especially promising for the ways they welcome the 'as-if', the generativity of marginality, the suspension of the 'what-has-been' and the 'what-is' to allow the trying out of the 'what-could-be'". The transformative potential of SaP, for Cook-Sather and Felten (2017, p. 187), is that is moves from beyond the margins by providing practitioners "a space within which to try out this collaborative way of being 'as if' it were a way of life."

Thus, transformation begins through our own active reflection and ongoing dialogue with others about who engages and why in partnership, what it means for higher education, and how we advocate for SaP more widely.

\section{CONCLUSION}

SaP does not follow 'step-by-step instructions' - it represents a multiplicity of practices predicated on power-sharing and reflectivity from all involved, which can make partnership challenging to enact. The first step is wanting to engage in genuine partnership, and this editorial was developed with that in mind. These five heuristic propositions provoke practitioners, and the broader collective movement, to ask difficult and sometimes 
uncomfortable questions about power, ethics, and equity in partnership. Not doing so risks SaP becoming elitist, exclusionary, and outcomes focused, while maintaining the traditional power structures within universities. Pondering these questions, alone, in partnership, and collectively, is necessary for the transformative potential of SaP to be realised.

\section{ACKNOWLEDGEMENTS}

Alison Cook-Sather, Peter Felten, Mick Healey, Beth Marquis, and Cherie Woolmer provided generous and insightful contributions that raised the quality of this piece in untold ways.

\section{NOTES ON CONTRIBUTOR}

Kelly E. Matthews is a Senior Lecturer of Higher Education at The University of Queensland in Brisbane, Australia, an Australian Learning \& Teaching Fellow, and an inaugural co-editor for the International Journal for Students as Partners.

\section{REFERENCES}

Barnacle, R. \& Dall'Alba, G. (2017). Committed to learn: student engagement and care in higher education. Higher Education Research \& Development, DOI: 10.1080/07294360.2017.1326879

Bell, A., Peseta, T., Barahona, S., Jeong, S., Lan, L., Menzies, R., Trieu, T., \& Wen, A. (2017). In conversation together: Student ambassadors for cultural competence. Teaching and Learning Together in Higher Education, 1(21), 5.

Bourdieu, P. (1988). Homo academicus. CA: Stanford University Press.

Bourdieu, P. (2003). Cultural reproduction and social reproduction. In R. Brown (Eds.) Knowledge, Education, and Cultural Change (pp. 71-112). London: Routledge.

Bovill, C. (2013). Students and staff co-creating curricula: An example of good practice in higher education. The student engagement handbook: Practice in higher education (pp. 461-475). Bingley: Emerald.

Bovill, C. (2017). A Framework to Explore Roles Within Student-Staff Partnerships in Higher Education: Which Students Are Partners, When, and in What Ways? International Journal of Students as Partners, 1(1).

Bovill, C., Cook-Sather, A., Felten, P., Millard, L., \& Moore-Cherry, N. (2016). Addressing potential challenges in co-creating learning and teaching: Overcoming resistance, navigating institutional norms and ensuring inclusivity in student-staff partnerships. Higher Education, 71(2), 195-208.

Bryson, C., Furlonger, R., \& Rinaldo-Langridge, F. (2016). A critical consideration of, and research agenda for, the approach of "students as partners." In Proceedings of 40th International Conference on Improving University Teaching, Faculty of Law, University of Ljubljana, Ljubljana, Slovenia, 15-17 July 2015. Retrieved from: http://www.iutconference.com/2016/01/a-critical-consideration-of-and-researchagenda-for-the-approach-of-students-as-partners/

Cook-Sather, A., \& Agu, P. (2013). Students of color and faculty members working together toward culturally sustaining pedagogy. In J. E. Groccia \& L. Cruz (Eds.), To improve the academy: Resources for faculty, instructional, and organizational development (Vol. 32, pp. 271-285). San Francisco: Jossey-Bass.

Cook-Sather, A., Bovill, C., \& Felten, P. (2014). Engaging students as partners in learning and teaching: A guide for faculty. San Francisco, CA: Jossey-Bass. 
Cook-Sather, A., \& Felten, P. (2017). Ethics of academic leadership: Guiding learning and teaching. In F. Su, \& M. Wood (Eds.), Cosmopolitan perspectives on academic leadership in higher education (pp. 175-191). London: Bloomsbury Academic.

Dewey, J. (1938). Experience and education. New York, NY: Macmillan.

Felten, P. (2017). Partnerships and emotion. International Journal of Students as Partners, $1(2)$.

Felten, P. (2013). Principles of good practice in SoTL. Teaching and Learning Inquiry: The ISSOTL Journal, 1(1), 121-125.

Felten, P., Gardner, J.N., Schroeder, C.C., Lambert, L.M., \& Barefoot, B.O. (2016). The undergraduate experience: Focusing institutions on what matters most. San Francisco, CA: Jossey-Bass.

Foucault, M. (1982). The subject and power. Critical inquiry, 8(4), 777-795.

Freeman, R. (2016) Is student voice necessarily empowering? Problematising student voice as a form of higher education governance. Higher Education Research \& Development, 35(4), 859-862.

Freire, P. (1970). Pedagogy of the oppressed. New York: Herder \& Herder.

Green, W. (2017). Engaging students as partners in global learning. Retrieved from http://altf.org/fellows/green-wendy/

Greene, M. (1994). Teaching for openings: Pedagogy as dialectic. In Sullivan P. A., Qualley D. J. (Eds.), Pedagogy in the age of politics: Writing and reading (in) the academy (pp. 112). Urbana, IL: National Council of Teachers of English.

Healey, M., Flint, A., \& Harrington, K. (2014). Students as partners in learning and teaching in higher education. York: Higher Education Academy. Retrieved from https://www.heacademy.ac.uk/system/files/resources/engagement through_partner ship.pdf

Healey, R. L., Bass, T., Caulfield, J., Hoffman, A., McGinn, M. K., Miller-Young, J., \& Haigh, M. (2013). Being ethically minded: Practising the scholarship of teaching and learning in an ethical manner. Teaching and Learning Inquiry: The ISSOTL Journal, 1(2), 23-33.

Kehler, A., Verwoord, R., \& Smith, H. (2017) We are the Process: Reflections on the underestimation of power in students as partners in practice. International Journal for Students as Partners, 1(1), 1-15.

Matthews, K.E. (2016). Students as partners as the future of student engagement. Student Engagement in Higher Education Journal, 1(1), 1-5.

Matthews, K.E. (2017). Students and staff as partners in Australian higher education: Introducing our stories of partnership. Teaching \& Learning Together in Higher Education, Issue 21.

Matthews, K.E, Cook-Sather, A., \& Healey, M. (in press). Connecting learning, teaching, and research through student-staff partnerships: toward universities as egalitarian learning communities. In V. Tong, A. Standen, A., \& M. Sotiriou, (Eds.) Research equals Teaching: Inspiring research-based education through student-staff partnerships. London: University College of London Press.

Mercer-Mapstone, L., Dvorakova, S.L., Matthews, K., Abbot, S., Cheng, B., Felten, P., Knorr, K., Marquis, E., Shammas, R., \& Swaim, K. (2017). A systematic literature review of students as partners in higher education. International Journal of Students as Partners, $1(1)$. 
Mihans, R., Long, D. \& Felten, P. (2008). Power and expertise: Student-faculty collaboration in course design and the scholarship of teaching and learning. International Journal for the Scholarship of Teaching and Learning, 2(2), 1-9.

Mills, C. (2008). Reproduction and transformation of inequalities in schooling: The transformative potential of the theoretical constructs of Bourdieu. British Journal of Sociology of Education, 29(1), 79-89.

Monsen, S., Cook, S., \& Hannant, L. (2017). Students as partners in negotiated assessment in a teacher education course. Teaching and Learning Together in Higher Education, Issue 21.

REACT Project (2017) Special Issue: Reaching hard to reach through student engagement. Journal of Educational Innovation, Partnership and Change, 3(1).

Seale, J., Gibson, S., Haynes, J., \& Potter, A. (2015). Power and resistance: Reflections on the rhetoric and reality of using participatory methods to promote student voice and engagement in higher education. Journal of Further and Higher Education, 39(4), 534552.

Schön, D. A. (1987). Educating the reflective practitioner. San Francisco: Jossey-Bass.

Shepherd, S. (2014). The rise of the career PVC. Engage 36. Leadership Foundation for Higher Education. Retrieved from: https://www.Ifhe.ac.uk/en/researchresources/publications-hub/past-editions/engage-36-autumn-2014/inpractice/index.cfm. 